\title{
PSMG2 Gene
}

National Cancer Institute

\section{Source}

National Cancer Institute. PSMG2 Gene. NCI Thesaurus. Code C104899.

This gene plays a role in assembly of the $20 \mathrm{~S}$ proteasome. 